\title{
Implementation of the Concept of Sustainable Development Based on Subsidiarity in Response to Current Dlobal Challenges
}

\author{
Lesya Korolchuk* \\ Lutsk National Technical University, Department of international economic relations, Lutsk, Ukraine
}

\begin{abstract}
With the current challenges of a globalized world, such as the crown virus pandemic and the growth of anti-globalization and antivaccination resistance movements around the world, the concept of sustainable development as a global strategy is under threat. There is a need to use such mechanisms and means of regulating global socioeconomic processes that would ensure the effective implementation of sustainable development strategy while eliminating the acute perception of the planet's population of the negative effects of globalization. The article substantiates the application of the principle of subsidiarity in the implementation of the concept of sustainable development through the prism of an inclusive approach, as well as on the basis of the theory of sustainable development and deductive method of scientific knowledge it is developed a model for implementing the global concept of sustainable development on the basis of subsidiarity, which is to delegate the tasks of implementing the global concept from the global to the local level within the economic, social and environmental components of sustainable development and to specify these tasks at the level of the average citizen and local authorities. The implementation of the proposed model provides the involvement of every inhabitant of the planet in the processes of sustainable development with the ideological and financial support of local authorities in a decentralized environment, which will achieve sustainable development goals and reduce public resistance to global challenges. Keywords: the concept of sustainable development, the principle of subsidiarity, an inclusive approach, anti-globalization movement, antivaccination.
\end{abstract}

The development of globalization in world economic processes, like anything new, has the experience of sharp criticism, rejection, and opposition. Thus, the hegemony of wealthy countries, the diligent work of transnational corporations and international organizations contributed to the emergence of the anti-globalization movement in the late 20th century. The comprehensive dictionary [1] interprets anti-globalism as a socio-political movement against international globalization, as in their opinion the negative consequences of this process far outweigh the positive ones.

\footnotetext{
${ }^{*}$ Corresponding author: 1.korolchuck@lutsk-ntu.com.ua
} 
Today, in the context of the crown virus pandemic, when the world is directly confronted with the challenges posed by globalization due to the increasing openness of national economies and international population mobility, the anti-globalization movement is gaining momentum. Many human casualties and the apparent helplessness of the world community in countering the spread of the virus have contributed to growing public distrust of the government and international organizations in particular.

Against the background of anti-globalization, a new branch is emerging anti-vaccination [2], as a broad civic movement that opposes vaccination against the coronavirus and denies its effectiveness and legitimacy. Based on the prevailing theory of global conspiracy, this state of affairs distorts the whole concept of sustainable development as the primary condition for the successful implementation of which see the reduction of the world's population. Anti-vaccines see the injection against the coronavirus as a means of combating the world's elite overpopulation.

Despite the above, the global concept of sustainable development must be best implemented to save our planet for future generations. We must be able to effectively control the crown virus pandemic globally to eliminate danger today and gain the ability to counter common threats in the future.

Thus, in the current conditions, it is necessary to apply such mechanisms, approaches and tools that would ensure the effective implementation of the concept of sustainable development on the one hand, as well as eliminate the sharp perception of the planet's adverse effects of globalization on the other. In this case, it is essential to transfer the relevant tools from the global plane, often immeasurable and far from the individual, to a lower local level - accessible, close and relevant to human life.

In the context of the above, we propose to apply the deductive method and inclusive approach, based on the theory of sustainable development, according to which the concept is based on three components [3]: economic, social and environmental.

Thus, as a method of scientific knowledge, the deduction will help us move away from the general global macroparameters of sustainable development, namely from its economic, social and environmental components to their micro manifestations at the local level.

In turn, the term "inclusion" is borrowed from the social sphere and confidently integrated into the economy at the beginning of the 21 st century, and can be interpreted according to E. Goldberg [4] and E. Pacetti-Garr [5] as ensuring equal participation of people in socio-economic activities, both at the state and global levels, in the implementation of the global concept of sustainable development based on justice and stability, in order to improve the quality of human life.

Thus, to ensure an inclusive approach to implementing the global concept of sustainable development, it is necessary to delegate various types of socio-economic activities from the global level to the local within the components of sustainable development. Such delegation provides the principle of subsidiarity, which F. Barca [6] interprets as the distribution of tasks according to activities between management levels, depending on where these tasks will be performed most effectively.

It follows that the global concept of sustainable development based on subsidiarity should provide for the transfer of tasks to its local levels within the economic, social and environmental components of sustainable development to mitigate the negative effects of globalization and to ensure a decent standard of living with our planet for future generations.

It should be noted that the implementation of the global strategy of sustainable development based on subsidiarity in favour of the local level justifies itself through more significant opportunities for local authorities to apply an inclusive approach to regulating socio-economic processes in the global world. As a result, every citizen will feel significant and involved in the world community and global ideology, will be able to feel the results of 
the global strategy in their lives, fear and mistrust will disappear, resistance to globalization will decrease, and humanity will be able to meet modern global challenges effectively.

The above allows us to model the implementation of the global concept of sustainable development based on subsidiarity, the results of which are shown in Figure 1. Thus, Figure 1 shows that sustainable development goals at the local level are specified in economic, social and environmental components based on a deductive approach to the theory of sustainable development.

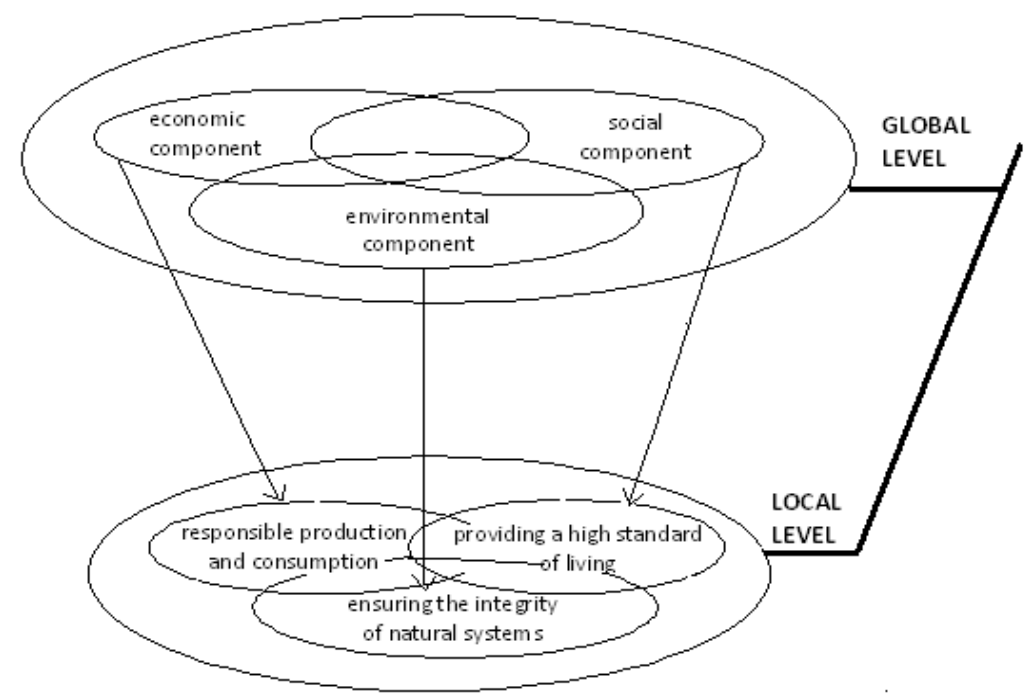

Fig. 1. The model of realization of the world concept of sustainable development based on subsidiarity

If the economic component of sustainable development at the global level involves optimizing the use of natural resources in production processes and maintaining economic growth of the economic system in terms of resource scarcity, then at the local level for the average citizen according to an inclusive approach is the task of responsible production, as a manufacturer-entrepreneur or production manager, by implementing the latest technologies, know-how and eco-innovations into production processes, saving resources and energy, eco-focusing product marking, extending the life cycle of goods, etc., as well as responsible consumption as a consumer of goods and services, by differentiating them according to the environmental criterion, cultivating a culture of economical and reconsumption of goods, sorting garbage and intelligent behaviour with waste, saving energy in everyday life, etc.

In turn, the social component of sustainable development at the global level involves human centrism and maintaining the stability of social and cultural systems, for which at the local level, the average citizen needs to take care of their health primarily in a pandemic crown virus, to be actively involved in sports and health sphere, to live and work in a stable and fair socio-economic environment with respect for fundamental human rights and freedoms, to have unhindered access to quality education and medicine, to grow and be educated based on freedom of choice, empathy and respect for people and nature.

The ecological component of sustainable development, which at the global level involves the preservation of our planet to ensure our livelihoods and for future generations of humanity, at the local level, the average resident faces the task of preserving the integrity of natural systems and species by caring for nature, flora and fauna in particular, 
introduction of ecological culture, active public work in the field of environmental protection, care for cleanliness and comfort in the native land, taking into account the environmental factor in all types of human activities, etc.

To fulfil the above tasks of implementing the concept of sustainable development, the average citizen at the local level needs comprehensive support from local authorities, as ideological through the formation and implementation of appropriate strategies for socioeconomic development of regions, publicity and promotion of healthy lifestyles, ecological life, ecological consumption, etc. and material through the financing of relevant projects and programs in various fields, economic incentives for sustainable development, development of quality infrastructure to ensure a decent standard of living, support for disadvantaged and low-income citizens, etc.

In conclusion, to increase the effectiveness of the global strategy for sustainable development based on subsidiarity in favour of the local level requires decentralization of power in nation-states, which should result in the delegation of power and financial freedom to regional and local levels. In Ukraine, such reform has taken place and is now successfully nearing completion. Therefore, under favourable conditions, it is time to develop relevant tools for an inclusive approach to regulating socio-economic processes globally, such as sustainable development.

\section{References}

1. J. Shveda, Political parties: Encyclopedic dictionary, 500 (2004). URL: https://web.archive.org/web/20131109163554/http://www.Inu.edu.ua/faculty/Phil/Shw eda_slovnyk.htm

2. M. Ifan, Covid anti-vaxxers: "Shut down fake news sites," begs daughter, BBC News, 6 August (2021). URL: from https://www.bbc.com/news/uk-wales-58103604

3. M. Kahn, Sustainable development: The key concepts, issues and implications, in Proceedings of the International Sustainable Development Research Conference, 2729 March 1995, Manchester, UK, Sustainable Development, 3, 63-69 (1995 ). URL: https://onlinelibrary.wiley.com/doi/pdf/10.1002/sd.3460030203

4. E. Goldberg, Amer. For. Pol. Inter., 6, 344-345 (2012).

5. E. Pacetti-Garr, The Five Characteristics of an Inclusive Economy: Getting Beyond the Equity Growth Dichotomy (Rockfeller Foundation, 2016). URL:

https://www.rockefellerfoundation.org/blog/fivecharacteristics-inclusive-economygetting-beyond-equity-growth-dichotomy/

6. F. Barca, An agenda for a reformed cohesion policy. A place-based approach to meeting European Union challenges and expectations. Independent Report prepared at the request of Danuta Hübner, Commissioner for Regional Policy, 219 (2009). URL: http://www.ecostat.unical.it/Dorio/Corsi/Corsi\%202017/Politiche\%20Sviluppo\%20Lo cale/Materiale\%20poleco/report_barca_v0306.pdf 